\title{
Pola pengasuhan 1.000 hari pertama kehidupan dan status gizi anak bawah dua tahun (baduta) di Kota Medan
}

\section{Childcare pattern during the first 1.000 days of life and nutrition status of children under the age of two years in Medan City}

\author{
Yuly Astuti*, Widayatun \\ Pusat Penelitian Kependudukan, Lembaga Ilmu Pengetahuan Indonesia \\ *Korespondensi penulis: yuly.astuti.19@gmail.com
}

\begin{abstract}
Health problems in the first 1.000 days of life have short- and long-term consequences for children under the age of two years. This study examines how the childcare pattern during the first 1.000 days of life affects the nutrition status of children under two in Medan City. This study is conducted by using mixed methods approach. A survey was performed to collect quantitative data of 400 households in 20 urban villages, whereas in-depth interviews and focus group discussions were conducted to collect qualitative data. In this study, childcare during the first 1.000 days of life includes colostrum feeding, early initiation of breastfeeding, exclusive breastfeeding, and complementary feeding practices. The study's findings show that mothers'education level is significantly associated to their knowledge of colostrum's benefit. Support from health providers and room-in policy needs to be improved to increase early initiation breastfeeding and exclusive breastfeeding. Additionally, mothers have even more variety of complementary feeding for children aged 6-24 months due to cultural practices and tradition. Thus, improving children under two's nutrition status requires comprehensive health promotion by considering sociocultural factors and evaluating the implementation of policies that support early initiation breastfeeding and exclusive breastfeeding practices.
\end{abstract}

Keywords: the first 1.000 days of life, colostrum, early initiation of breastfeeding, exclusive breastfeeding, complementary feeding practices

\begin{abstract}
ABSTRAK
Gangguan kesehatan pada periode 1.000 hari pertama kehidupan (HPK) menimbulkan dampak kesehatan jangka pendek dan jangka panjang pada anak usia kurang dari dua tahun (baduta). Studi ini bertujuan untuk mengkaji pola pengasuhan 1.000 HPK yang memengaruhi status gizi baduta di Kota Medan. Pengumpulan data dilakukan melalui pendekatan penelitian campuran (mixed methods). Data kuantitatif berasal dari survei terhadap 400 rumah tangga di 20 kelurahan di Kota Medan. Sementara itu, data kualitatif diperoleh dari hasil wawancara mendalam dan diskusi kelompok terpumpun (DKT) dengan ibu yang memiliki anak baduta. Dalam studi ini pola pengasuhan pada 1.000 HPK meliputi pemberian kolostrum, praktik inisiasi menyusu dini (IMD), pemberian ASI eksklusif, dan pemberian makanan pendamping ASI. Hasil penelitian menunjukkan tingkat pendidikan ibu sangat terkait dengan pemahaman yang tepat mengenai manfaat kolostrum. Dukungan tenaga kesehatan dan kebijakan penempatan bayi di satu ruangan yang sama dengan ibu setelah dilahirkan masih perlu ditingkatkan untuk mendukung praktik IMD dan ASI eksklusif. Selain itu, tradisi budaya masih memengaruhi pemberian makanan pendamping ASI, khususnya untuk anak usia 6-24 bulan. Oleh karena itu, upaya alternatif untuk meningkatkan status gizi baduta dapat dilakukan melalui promosi kesehatan dengan mempertimbangkan faktor sosial budaya serta mengevaluasi implementasi kebijakan yang mendukung praktik IMD dan ASI eksklusif.
\end{abstract}

Kata kunci:1.000 HPK, kolostrum, IMD, ASI eksklusif, makanan pendamping ASI 


\section{PENDAHULUAN}

Seribu hari pertama kehidupan (1.000 HPK) adalah fase kehidupan yang dimulai sejak terbentuknya janin dalam kandungan sampai anak berusia dua tahun (baduta). Periode 1.000 HPK sangat penting karena pertumbuhan dan perkembangan seluruh organ serta sistem tubuh terjadi pada saat tersebut. Secara ilmiah, periode 1.000 HPK merupakan periode penentu sumber daya manusia yang berkualitas di masa yang akan datang. Dengan demikian, periode ini dikenal dengan sebutan 'periode emas' atau windows of opportunity (Kementerian Kesehatan, 2018; UNICEF, 2013). Terganggunya periode 1.000 HPK menimbulkan berbagai permasalahan gizi buruk (undernutrition) pada anak usia di bawah lima tahun, meliputi kurus (wasting), gizi kurang (underweight), dan pendek (stunting) (WHO, 2013). Data Riset Kesehatan Dasar (Riskesdas) tahun 2018 menyebutkan sebanyak 10,2\% baduta termasuk dalam kategori kurus, $17,7 \%$ dan $30,8 \%$ lainnya masing-masing menderita gizi kurang dan stunting (Balitbangkes Kemenkes, 2019a).

Dampak kesehatan yang ditimbulkan dari gizi kurang bersifat jangka pendek dan jangka panjang. Dampak kesehatan jangka pendek berupa penurunan sistem kekebalan tubuh yang pada akhirnya dapat menyebabkan timbulnya berbagai penyakit infeksi pada anak bawah lima tahun (balita), meningkatkan kematian pada anak balita, serta memengaruhi kecerdasan dan tumbuh kembang (Aguayo \& Menon, 2016; Black dkk., 2008; Black dkk., 2013; Kim dkk., 2017). Sementara itu, dampak jangka panjang dari gizi kurang antara lain memengaruhi performa belajar pada usia sekolah dan dewasa serta menimbulkan penyakit tidak menular di kemudian hari, seperti diabetes dan hipertensi (Kim dkk., 2017; Perkins dkk., 2017; Victora dkk., 2008; Young dkk., 2018).

Kerangka konseptual UNICEF (2013) menunjukkan bahwa terdapat faktor langsung dan faktor tidak langsung yang memengaruhi gizi buruk pada anak balita. Faktor makanan dan penyakit infeksi (keduanya saling memengaruhi) adalah faktor langsung yang menentukan status gizi individu. Kebutuhan nutrisi anak usia 0-2 tahun meliputi praktik pemberian air susu ibu
(ASI) yang memadai (pemberian kolostrum, inisiasi menyusu dini, ASI eksklusif, dan lamanya pemberian ASI) dan praktik penyediaan makanan pendamping (makanan prelakteal, waktu pemberian makanan pendamping selain ASI untuk balita dan jenis makanan pendamping) (UNICEF, 2013).

Data profil kesehatan Indonesia tahun 2019 mengungkapkan bahwa cakupan ASI eksklusif sebesar $67,7 \%$ dan inisiasi menyusu dini (IMD) dilakukan pada 75,6\% bayi baru lahir (Kementerian Kesehatan, 2020). Cakupan ASI eksklusif dan IMD tersebut sudah melebihi target rencana strategis yang ditetapkan oleh pemerintah, masing-masing sebesar $50 \%$. Namun, tingginya balita kurus (10,2\%), gizi kurang $(17,7 \%)$, dan stunting (30,8\%) menunjukkan Indonesia masih menghadapi permasalahan kesehatan serius akibat status gizi baduta yang buruk (Kementerian Kesehatan, 2020).

ASI mengandung semua nutrisi yang dibutuhkan bayi dalam enam bulan pertama kehidupan. Selanjutnya, memasuki usia enam bulan kebutuhan gizi bayi semakin meningkat. Pemberian makanan pendamping ASI yang kaya nutrisi diperlukan untuk mendukung tumbuh kembang bayi. Selama periode 6-24 bulan, makanan pendamping ASI diberikan secara bertahap dari bentuk encer menjadi bentuk yang lebih kental dengan berbagai variasi diet, yang paling tidak terdiri dari empat jenis sumber protein dan vitamin yang berbeda, seperti biji-bijian dan umbi-umbian; kacang-kacangan; produk susu olahan, seperti keju; daging, meliputi daging sapi, unggas, ikan; telur; buah dan sayur yang mengandung vitamin A tinggi; buah-buahan dan jenis sayuran lainnya (WHO, 2013).

Sementara itu, faktor penyebab tidak langsung gizi kurang balita dipengaruhi oleh pola asuh pada periode 1.000 HPK. Hasil studi terdahulu menyebutkan bahwa pola pengasuhan melalui praktik pemberian makan yang tepat dapat mendukung perkembangan, pertumbuhan serta kelangsungan hidup balita (Katepa-Bwalya dkk., 2015; Saaka, 2014; Bbaale, 2014). Berbagai literatur menyebutkan bahwa variabel sosial demografi memiliki hubungan yang kuat dengan pola pengasuhan anak balita. Tingkat pendidikan ibu 
merupakan salah satu variabel sosial demografi yang mempunyai pengaruh kuat terhadap pengasuhan anak (Bbaale, 2014; Frosta dkk., 2005; Alderman dkk., 2003). Bbaale (2014) menyebutkan bahwa ibu dengan tingkat pendidikan tinggi lebih mungkin untuk mengelola makanan dan gizi yang tepat serta memanfaatkan pelayanan kesehatan untuk anak balita. Hasil penelitian yang sama menjelaskan sebesar $41 \%$ anak-anak dari ibu dengan tingkat pendidikan rendah mengalami stunting, sedangkan hanya $23 \%$ anak-anak dari ibu dengan tingkat pendidikan tingkat menengah ke atas mengalami kondisi yang sama.

Beberapa penelitian terdahulu juga mengindikasikan bahwa pemberian ASI eksklusif dapat mengurangi kemungkinan terjadinya stunting sebesar 1,26-6,68 kali (Aguayo \& Menon, 2016; Berhe dkk., 2019; Bukusuba dkk., 2018; Tariku dkk., 2017). Penelitian di Ethiopia menunjukkan kolostrum yang diperoleh bayi pada saat IMD dapat mencegah stunting dengan probabilitas sebesar 4,45-5,72 kali (Batiro dkk., 2017; Kahssay dkk., 2020). Dengan demikian, temuan penelitian terdahulu memperkuat bukti dampak pola pengasuhan terhadap kejadian gizi buruk pada baduta.

Variabel lain yang memengaruhi pola pengasuhan anak balita adalah budaya dan etnisitas. Adanya pantangan makanan untuk ibu hamil, ibu menyusui, dan pembatasan pemberian jenis makanan tertentu untuk anak balita merupakan bentuk pengaruh budaya tertentu dalam pengasuhan anak (Fouts dkk., 2012; Aubel, 2011; Liamputtong, 2011). Faktor penting lainnya yang memengaruhi pola pengasuhan anak balita adalah peran dan dukungan sosial yang berasal dari anggota keluarga terdekat ibu, seperti suami, orang tua, serta tenaga kesehatan (Thulier \& Mercer, 2009). Orang tua umumnya menerapkan pola pengasuhan anak balita berdasarkan pengalaman mereka (Masvie, 2006; Ingram dkk., 2003).

Kota Medan merupakan salah satu kota di Provinsi Sumatera Utara yang masih menghadapi permasalahan kesehatan anak baduta. Kematian bayi dan balita di wilayah ini sebanyak $25 \mathrm{ka}-$ sus dari jumlah total 39.029 kelahiran hidup pada tahun 2018 (Dinas Kesehatan Provinsi Sumatera Utara, 2019). Sekitar 0,4\% kelahiran di kota ini berada dalam kondisi berat badan lebih rendah (BBLR) dari berat badan bayi pada kisaran normal. Selain itu, cakupan ASI ekslusif Kota Medan hanya sekitar 34,5\% (kurang lebih 4.506 anak usia di bawah enam bulan). Angka ini sedikit lebih rendah dibandingkan cakupan ASI eksklusif di tingkat provinsi (34,9\% atau sekitar 51.392 anak usia di bawah enam bulan) (Dinas Kesehatan Provinsi Sumatera Utara, 2019). Berbagai permasalahan kesehatan anak balita di Kota Medan ditengarai akibat belum optimalnya pengasuhan anak yang diterapkan pada periode 1.000 HPK. Tulisan ini bertujuan untuk mengkaji pola pengasuhan yang memengaruhi status gizi baduta di Kota Medan.

\section{POLA PENGASUHAN DAN KESEHATAN BADUTA: KAJIAN LITERATUR}

Definisi pola pengasuhan bayi dalam periode 1.000 HPK dalam studi ini diartikan sebagai pemberian makanan bernutrisi yang meliputi pemberian kolostrum, praktik IMD, ASI eksklusif serta pemberian makanan pendamping ASI untuk baduta. Berbagai kajian menyebutkan bahwa pola pengasuhan bayi dipengaruhi oleh faktor sosialdemografi, seperti umur ibu, tingkat pendidikan ibu, pengetahuan ibu, dan tradisi/budaya (Teka dkk., 2015; Onah dkk., 2014; Meedya dkk., 2010; Thulier \& Mercer, 2009; Wagner dkk., 2006).

Menyusui segera setelah bayi baru lahir sangat berperan dalam menurunkan angka kematian bayi (Teka dkk., 2015). Hal tersebut dikarenakan kolostrum - ASI yang keluar pertama kali berwarna kekuningan dengan tekstur kental - mengandung zat kekebalan tubuh sebanyak 1017 kali lebih banyak daripada ASI. Kolostrum berfungsi sebagai imunisasi alami bagi bayi yang baru lahir, memperkuat sistem kekebalan tubuh, dan mengurangi kemungkinan kematian pada periode neonatal (Teka dkk., 2015; Thulier \& Mercer, 2009).

Selanjutnya, IMD adalah proses pemberian ASI segera (dalam jangka waktu satu jam) setelah bayi dilahirkan (Kementerian Kesehatan, 2018). Berbagai bukti menyebutkan manfaat yang diperoleh dari IMD yang diberikan dalam kurun waktu satu jam setelah bayi dilahirkan (Onah dkk., 2014; Wagner dkk., 2006). Sekitar 22\% kematian 
bayi usia 0-12 bulan dapat dicegah melalui IMD yang diberikan dalam kurun waktu yang tepat. Kontak kulit-ke-kulit yang dilakukan sejak awal merupakan faktor penting dalam mencegah hipotermia (kondisi suhu tubuh yang turun secara drastis hingga di bawah 35 derajat Celsius) dan membangun ikatan antara ibu dan anak. IMD juga mengurangi risiko pendarahan paska persalinan yang merupakan salah satu penyebab utama kematian ibu (Mullany dkk., 2008).

Penyediaan asupan gizi optimal untuk bayi 0-6 bulan juga harus dilakukan melalui pemberian ASI eksklusif. WHO (2013) menganjurkan pemberian ASI dilanjutkan hingga bayi berusia dua tahun. Pemberian ASI memperkuat sistem kekebalan tubuh bayi serta mengurangi kematian balita (Gross dkk., 2011; Katepa-Bwalya dkk., 2015; Thulier \& Mercer, 2009). Setelah bayi berusia enam bulan, pemberian ASI dikombinasikan dengan makanan pendamping ASI sebagai upaya pemenuhan kecukupan gizi anak baduta di 'periode emas' (Gross dkk., 2011).

Penelitian sebelumnya menunjukkan bahwa terdapat hubungan antara menyusui dan kecerdasan anak di kemudian hari (Black dkk, 2013; Victora dkk, 2008). Namun demikian, prevalensi pemberian ASI eksklusif masih rendah. Berbagai faktor memengaruhi keberhasilan pemberian ASI eksklusif, seperti pengetahuan ibu mengenai pentingnya ASI bagi tumbuh kembang anak usia 0-24 bulan, peran keluarga (termasuk suami dan orang tua), dan yang tidak kalah penting adalah motivasi yang kuat dari ibu untuk memberikan ASI kepada bayinya (Katepa-Bwalya dkk., 2015; Thulier \& Mercer, 2009).

Studi menunjukkan bahwa pemberian makanan pendamping ASI yang tepat, memadai, dan aman sejak anak berusia enam bulan menentukan kondisi kesehatan dan pertumbuhan bayi (Katepa-Bwalya dkk., 2015; Thulier \& Mercer, 2009). Pemberian makanan pendamping ASI terlalu dini (sebelum anak usia enam bulan) dapat menyebabkan dampak negatif, seperti bayi rentan terhadap penyakit pada saluran pencernaan (seperti diare) dan peningkatan angka kematian bayi (Katepa-Bwalya dkk., 2015; Mekuria \& Edris, 2015). Sementara itu, penundaan pemberian makanan pendamping ASI akan menghambat pertumbuhan bayi karena zat gizi yang dihasilkan dari ASI tidak lagi mencukupi kebutuhan tumbuh kembang anak usia 6-24 bulan (Katepa-Bwalya dkk., 2015; UNICEF, 2013). Pemberian makanan tambahan ASI ditentukan oleh tingkat pengetahuan ibu. Namun, studi Saaka (2014) menyebutkan pengetahuan yang dimiliki ibu mengenai makanan pendamping ASI yang sehat dan aman bagi anak usia 6-24 bulan seringkali tidak sesuai dengan praktik yang diterapkan ibu ketika memberikan makanan pendamping tersebut.

\section{METODOLOGI}

Data yang digunakan untuk penulisan artikel ini berasal dari data primer dengan menggunakan metode pendekatan penelitian campuran (mixed methods) kualitatif dan kuantitatif. Penelitian kualitatif yang dilakukan pada tahun 2016 bertujuan untuk memperoleh gambaran umum pola pengasuhan baduta di Kota Medan. Untuk memperoleh gambaran yang lebih komprehensif mengenai pengaruh faktor sosial ekonomi dengan pengasuhan anak baduta dilakukan survei pada tahun 2017. Akibat adanya keterbatasan beberapa variabel dalam survei, pengumpulan data kualitatif lanjutan dilakukan pada tahun 2018 untuk menggali informasi secara lebih mendalam terkait faktor sosial budaya dan peran keluarga dalam pengasuhan baduta. Pengumpulan data lanjutan juga dilakukan untuk menggali informasi spesifik dari kelompok ibu bekerja. Hal ini dikarenakan jumlah responden ibu bekerja pada survei tahun 2017 kurang dapat mengintepretasikan hasil uji statistik yang digunakan.

Data kuantitatif dalam studi ini berasal dari hasil survei 'Determinan sosial perilaku kesehatan ibu dan pola pengasuhan anak di era globalisasi di Kota Medan' yang dilakukan pada tahun 2017 oleh Pusat Penelitian Kependudukan Lembaga Ilmu Pengetahuan Indonesia (LIPI). Teknik sampling two stages probability proportional to size (PPS) digunakan untuk memilih lokasi kajian. Sampling tahap pertama dilakukan untuk memilih kelurahan secara acak. Sebanyak 20 kelurahan dari total 151 kelurahan di 12 kecamatan di Kota Medan dipilih sebagai lokasi survei. Selanjutnya, sampling tahap kedua dilakukan untuk memilih responden di tingkat rumah tangga 
dengan menggunakan teknik purposive snowballing. Sebanyak 20 responden dipilih di setiap kelurahan yang terpilih pada tahap sampling sebelumnya. Dengan demikian, total responden survei ini sebanyak 400 orang ibu yang memiliki anak kandung berusia 0-24 bulan.

Dengan mempertimbangkan ketersediaan variabel di dalam survei, variabel terikat yang digunakan dalam studi ini adalah praktik pemberian kolostrum, IMD, ASI eksklusif, dan makanan pendamping ASI. Variabel tersebut diklasifikasikan dalam dua kategori "ya" dan "tidak". Sementara itu, variabel bebas dalam studi ini meliputi tingkat pendidikan ibu dan metode persalinan. Untuk analisis statistik, selain analisis deskriptif, uji regresi logistik digunakan untuk menguji faktor-faktor yang memengaruhi pola pengasuhan pada periode 1.000 HPK.

Data hasil penelitian pendekatan kualitatif diperoleh dari wawancara mendalam dengan sembilan orang ibu yang memiliki anak berusia di bawah dua tahun serta empat orang nenek (ibu dari responden) yang mengasuh cucunya. Melalui metode purposive sampling, ibu yang menjadi responden untuk studi dengan pendekatan kualitatif dibagi menjadi empat kategori berdasarkan tingkat pendidikan dan status bekerja ibu, yakni bekerja, tidak bekerja, tingkat pendidikan tamat sekolah menengah atas (SMA) dan perguruan tinggi, dan tingkat pendidikan tamat sekolah menengah pertama (SMP) ke bawah. Selain itu, diskusi kelompok terpumpun (DKT; focus group discussion/FGD) dilakukan sebanyak tiga kali dengan target ibu bekerja maupun ibu rumah tangga. Tiap FGD melibatkan sekitar 8-10 orang ibu yang memiliki baduta di Kota Medan. Data kualitatif yang terkumpul dianalisis menggunakan teknik analisis deskriptif tematik. Jawaban dan respons yang diungkapkan oleh responden dikelompokkan berdasarkan kata-kata maupun kalimat sesuai dengan tema dan kemudian dianalisis lebih lanjut untuk menjawab tujuan studi.

\section{HASIL DAN PEMBAHASAN}

\section{Kondisi Kesehatan Balita di Kota Medan}

Kota Medan termasuk ke dalam 16 kabupaten/ kota di Provinsi Sumatera Utara yang memiliki prevalensi kasus balita gizi buruk dan kurang yang lebih tinggi dari rata-rata angka provinsi (Balitbangkes Kemenkes, 2019a). Bahkan, pada tahun 2019, Kota Medan menempati urutan pertama kasus gizi buruk dari 26 kabupaten/kota di Provinsi Sumatera Utara (Balitbangkes Kemenkes, 2019b). Kota Medan juga masih menghadapi permasalahan akibat tingginya prevalensi stunting untuk anak usia kurang dari lima tahun. Meskipun prevalensi stunting di kota ini mengalami penurunan dalam kurun waktu 2013-2018, satu dari empat anak balita menderita stunting seperti terlihat pada Gambar 1. Prevalensi stunting di Kota Medan lebih rendah apabila dibandingkan dengan prevalensi stunting di Provinsi Sumatera Utara.

Masih tingginya kasus balita gizi buruk dan kurang di Kota Medan dapat dikaitkan dengan

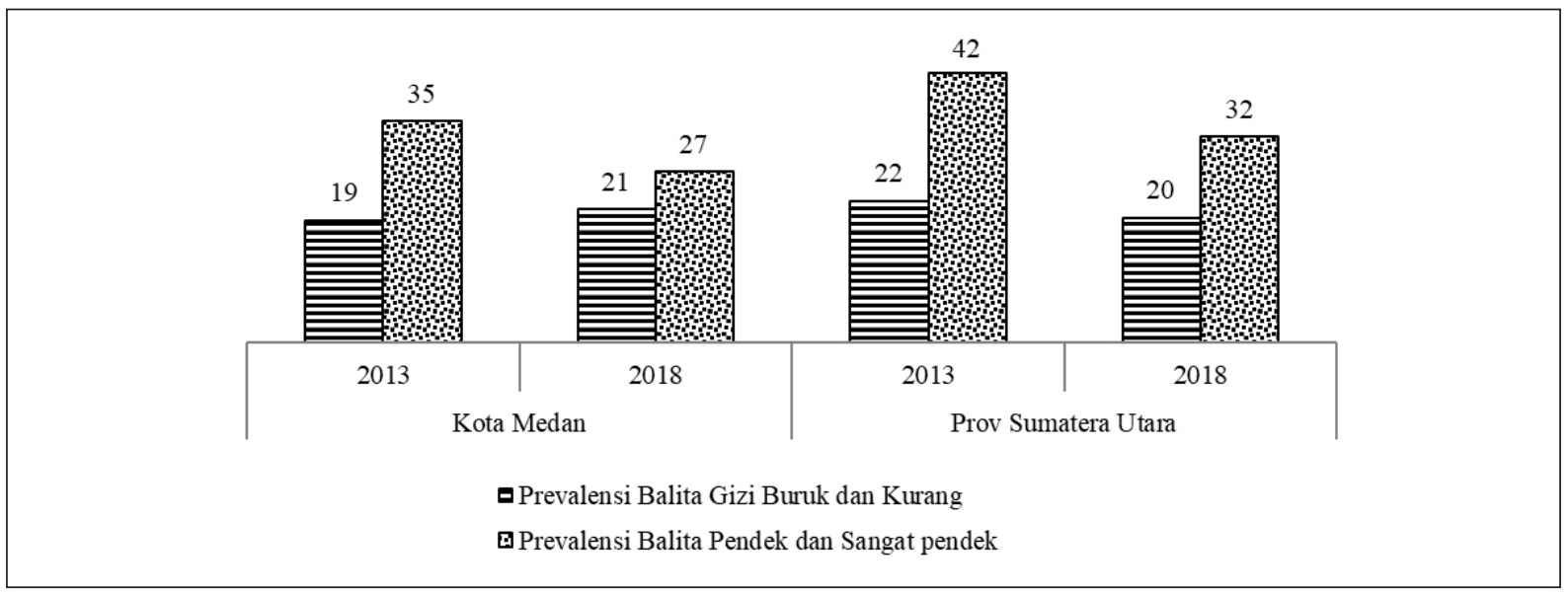

Sumber: Indeks Pembangunan Kesehatan Masyarakat Tahun 2018 Tabel L.006 (Balitbang Kemenkes, 2019b)

Gambar 1. Indikator Kesehatan Balita, Kota Medan, pada 2013 dan 2018 
belum optimalnya pemberian ASI eksklusif. Seperti sudah disebutkan sebelumnya, cakupan ASI di Kota Medan baru mencapai 34,5\% (Dinas Kesehatan Provinsi Sumatera Utara, 2019). Untuk memperkuat justifikasi permasalahan kesehatan baduta akibat pola pengasuhan yang kurang tepat, hasil survei Pusat Penelitian Kependudukan LIPI pada tahun 2017 menunjukkan bahwa dari 254 ibu yang memiliki anak usia 9-24 bulan, sebagian besar ibu (47,6\%) menerapkan pola asuh dalam kategori sedang, 33,1\% ibu menerapkan pola asuh kurang baik dan hanya 19,3\% ibu yang menerapkan pola asuh baik untuk baduta. Definisi pola asuh kurang baik dalam survei tersebut adalah ibu yang tidak memberikan IMD, ASI eksklusif dan makanan pendamping ASI tepat waktu. Sementara, pola asuh sedang adalah ibu yang memberikan salah satu praktik pola pengasuhan sesuai dengan pedoman, baik itu IMD, ASI eksklusif maupun makanan pendamping ASI. Pola asuh baik adalah ibu yang memberikan IMD, ASI eksklusif, dan makanan pendamping ASI sesuai dengan pedoman yang ditetapkan oleh Kementerian Kesehatan (Astuti \& Widayatun, 2019).

\section{Faktor yang Berhubungan dengan Pola Pengasuhan 1.000 HPK pada Baduta di Kota Medan}

Indikator yang digunakan untuk menggambarkan pola pengasuhan anak usia 0-24 bulan di Kota Medan adalah pemberian kolostrum, praktik IMD, pemberian ASI eksklusif selama enam bulan pertama, dan pemberian makanan pendamping ASI. Gambar 2 memperlihatkan pola pengasuhan anak berumur 0-24 bulan di Kota Medan berdasarkan empat indikator tersebut.

\section{Pemberian Kolostrum}

Pemberian kolostrum pada ibu yang mempunyai anak 0-24 bulan di Kota Medan tergolong belum cukup baik $(80,3 \%)$. Angka ini relatif lebih rendah apabila dibandingkan dengan pemberian kolostrum di tingkat nasional berdasarkan hasil Riskesdas 2018 sebesar 85,3\%. Namun, cakupan pemberian kolostrum di Kota Medan masih lebih tinggi dibandingkan dengan angka di tingkat Provinsi Sumatera Utara sebesar 72,2\% (Balitbangkes Kemenkes, 2019a). Tidak optimalnya pemberian kolostrum pada bayi baru dipengaruhi oleh berbagai faktor, antara lain kurangnya pengetahuan mengenai manfaat kolostrum (Katepa-Bwalya dkk., 2015). Temuan penelitian ini sejalan dengan hasil Riskesdas yang menyebutkan bahwa semakin tinggi pendidikan ibu, semakin tinggi pula tingkat pemberian kolostrum (Balitbangkes Kemenkes, 2019a).

Hasil survei menunjukkan masih adanya anggapan yang salah mengenai manfaat kolostrum di kalangan responden dengan anak balita usia 0-24 bulan (Gambar 3). Sebanyak 31,6\% responden menyebutkan kolostrum merupakan susu kotor dan dapat menyebabkan penyakit untuk bayi baru lahir. Temuan ini diperkuat dengan berbagai hasil wawancara dan FGD dengan ibu dengan latar belakang pendidikan rendah (tamat SMP ke bawah). Wawancara mendalam dengan ibu berpendidikan rendah menyebutkan bahwa kolostrum akan berpengaruh buruk terhadap kesehatan

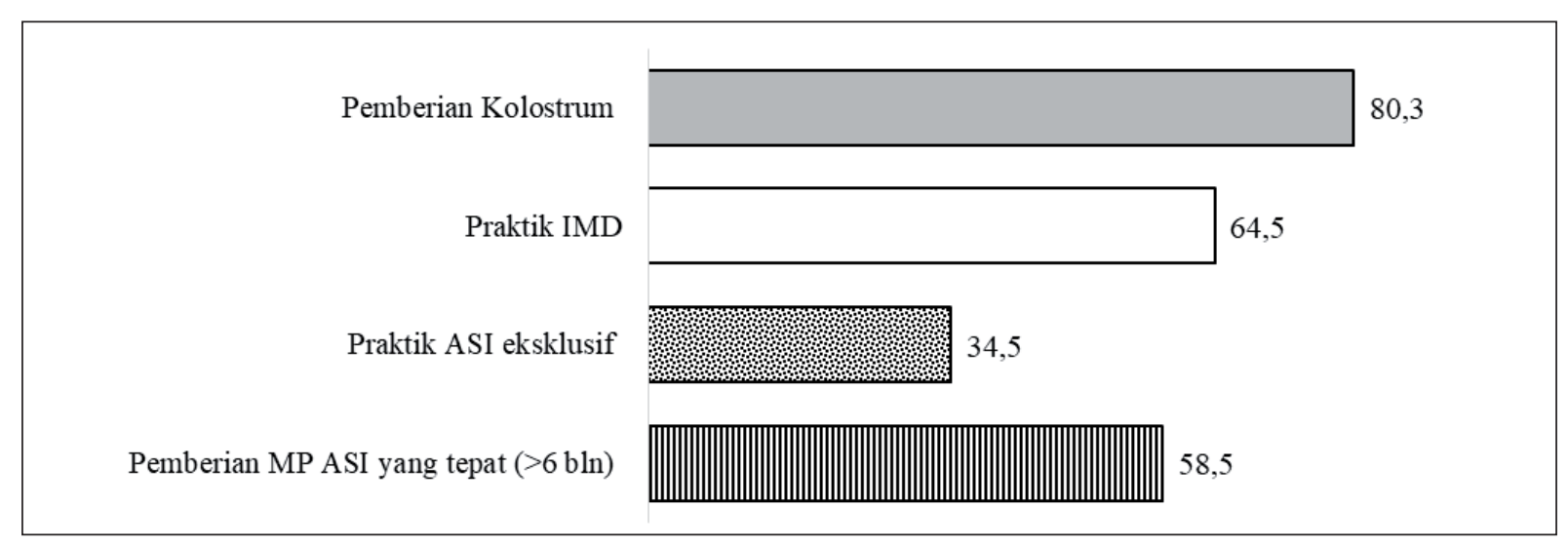

Sumber: Survei determinan sosial perilaku kesehatan ibu dan pola pengasuhan anak di era globalisasi di Kota Medan, P2 Kependudukan LIPI, tahun 2017

Gambar 2. Persentase pemberian kolostrum, IMD, ASI eksklusif, dan makanan pendamping ASI, Kota Medan, 2017. 


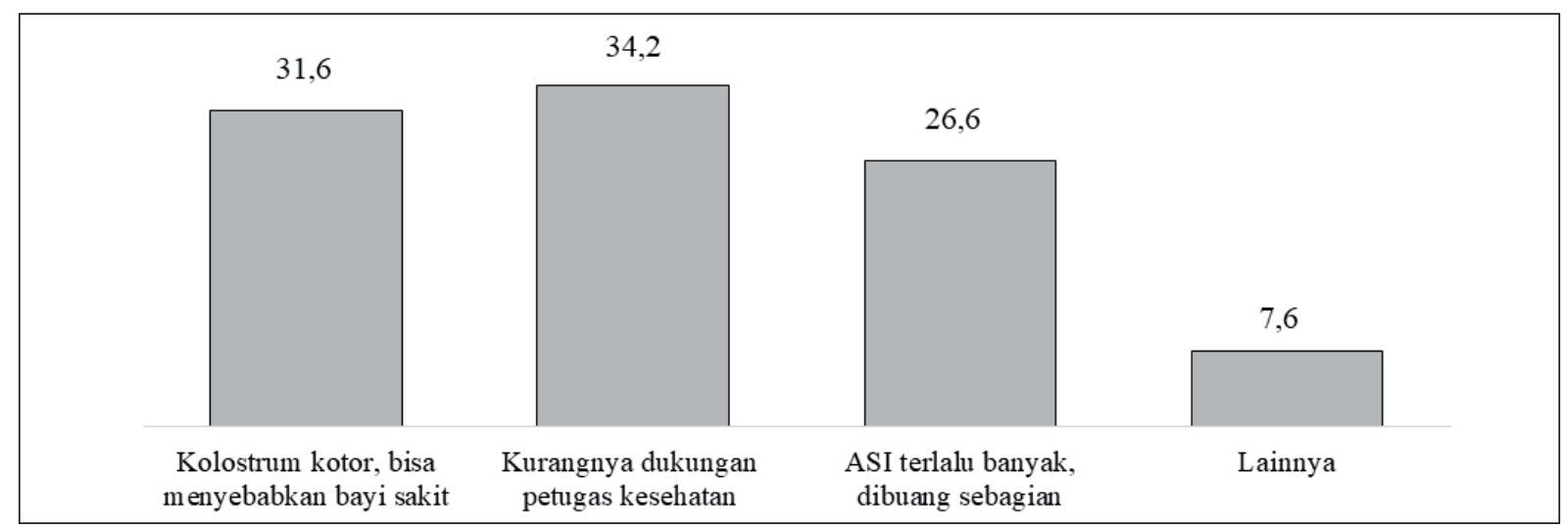

Sumber: Survei determinan sosial perilaku kesehatan ibu dan pola pengasuhan anak di era globalisasi di Kota Medan, P2 Kependudukan LIPI, tahun 2017

Gambar 3. Proporsi Alasan Ibu Tidak Memberikan Kolostrum pada Bayi, Kota Medan, 2017

anak karena warnanya yang kekuningan dan teksturnya yang lebih kental dibanding ASI. Pengetahuan yang kurang tepat ini umumnya diperoleh ibu dari orang tua mereka (Astuti dkk., 2016; Astuti \& Widayatun, 2018a). Kutipan wawancara dengan ibu yang memiliki latar belakang pendidikan SMP ke bawah menggambarkan pemahaman yang kurang tepat mengenai kolostrum.

ASI yang baru pertama kali keluar dibuang dulu, dibersihin terus diperes karena kan masih seperti getah itu. Kalau kata orang tua saya dulu bilangnya kan itu susu basi. Bisa bikin anak sakit, ntah kembung nanti perutnya atau lainnya, pokoknya tidak bagus itu, karena warnanya saja kan berbeda dari air susu $(\mathrm{KS}$, tamat SD, tidak bekerja)

ASI pertama saya buang sedikit supaya bersih dulu. Kata orang tua itu susu basi. Karena itu kan beda warnanya sama susu ASI, kentalkental gitu. Kata bidan itu bagus, tapi kan itu tidak bersih kaya ASI, jadi daripada anak saya sakit, kata mamak itu dibuang saja (YN, tamat SMP, tidak bekerja)

Praktik pemberian kolostrum tidak hanya berkaitan dengan tingkat pendidikan ibu, tetapi juga dipengaruhi oleh sosialisasi dari petugas kesehatan mengenai manfaat kolostrum (Astuti dkk., 2016; Astuti \& Widayatun, 2019). Uji regresi logistik menunjukkan ibu yang tidak memperoleh informasi dari petugas kesehatan mengenai manfaat kolostrum berpeluang untuk tidak memberikan kolostrum 4,5 kali lebih besar dibanding ibu yang memperoleh informasi tepat mengenai kolostrum dari petugas kesehatan.
Hasil kualitatif mengungkapkan informasi dari petugas kesehatan mengenai pentingnya pemberian kolostrum untuk bayi baru lahir menjadi salah satu faktor yang dapat menghilangkan anggapan yang kurang tepat mengenai kolostrum akibat adanya pengaruh dari faktor budaya di kalangan penduduk Kota Medan.

Awalnya mamak itu bilang terus pas saya hamil, kalau nanti susu kolostrum yang kuning itu harus dibuang karena bahaya untuk bayi. Tapi kan saya bilang mamak, kalau setiap posyandu itu bidan bilang itu susu bagus, banyak manfaatnya. Kalau pas periksa hamil juga bu bidan kasih tau terus kalau kolostrum itu bagus, banyak manfaatnya, bikin anak kita itu sehat terus, ga gampang sakit. Jadi, ya saya percaya saja sama ibu bidan (ST, tamat SMA, bekerja)

Kalau pas periksa hamil di posyandu itu bidan bilang pokoknya susu yang kuning kental itu harus dikasih ke bayi. Bagus itu nggak apa-apa lengket, tapi itu bikin anak kita sehat terus. Pas baru lahir bidan kan langsung kasih bayi ke kita, jadi saya langsung kasih. Mamak sempat bilang ke bidan kalau itu susu harus dibuang karena susu basi, tapi kan ibu bidan lebih pintar. Jadi saya ikut apa kata ibu bidan (AN, tamat SMP, tidak bekerja)

Saya ikut nurut kata bidan saja, walaupun kalau mamak kasih tau saya juga tidakjawab apa-apa. Katanya kan itu susu basi kalau mamak bilang. Tapi pas anak lahir, bidan langsung kasih ke saya bayinya dan apa itu menyusui dini itu langsung dikasih, jadi ya saya juga pencet 2 itu susu yang kuning biar masuk ke mulut dedeknya (Hasil DKT dengan ibu rumah tangga). 
Kalau kita sih ikut aja apa kata ibu bidan kalau pas penyuluhan di Puskesmas itu. Pas periksa hamil juga kan suka kita itu ibu hamil disusuh duduk bersama. Iya ibu bidan bilang kalau kolostrum itu bagus, kalau ada mamak kita yang bilang itu susu basi itu sebenarnya salah. Justru itu karena apa itu namanya untuk daya tahan tubuh, makanya warnanya kuning-kuning kental itu sebenarnya bagus untuk bayi. Mamak saja masih kuno karena dia kan juga tidak tau itu (Hasil DKT dengan ibu bekerja)

Gambar 3 menunjukkan bahwa 34,2\% responden tidak memberikan kolostrum kepada bayinya dengan alasan kurangnya dukungan dari petugas kesehatan untuk memberikan kolostrum bagi bayi baru lahir. Hal ini antara lain diakibatkan karena penempatan ibu dan bayi baru lahir di ruangan yang terpisah. Uji regresi logistik menemukan ibu yang diletakkan di ruangan terpisah dengan bayi yang baru dilahirkannya berpeluang untuk tidak memberikan kolostrum sebesar 2,1 kali dibandingkan dengan ibu yang berada di ruangan yang sama dengan bayinya setelah melahirkan. Kementerian Kesehatan sejak tahun 2012 mengimplementasikan program 'Gerakan menyusui pada satu jam pertama menyelamatkan satu juta nyawa bayi'.

Program ini mewajibkan petugas kesehatan yang menangani persalinan untuk membantu ibu memberikan kolostrum bagi bayi baru lahir. Namun demikian, temuan studi di Kota Medan mengindikasikan program ini belum berjalan efektif. Selanjutnya, sebanyak 26,6\% ibu membuang ASI karena produksinya yang terlalu banyak. Kondisi ini menyebabkan ikut terbuangnya kolostrum yang seharusnya diberikan kepada bayi baru lahir. Tidak hanya itu, sebanyak 7,6\% ibu mengungkapkan tidak memberikan kolostrum kepada bayi baru lahir karena alasan ASI yang tidak keluar dan dada terasa sakit (Astuti \& Widayatun, 2019).

\section{Inisiasi Menyusu Dini (IMD)}

Keberhasilan pelaksanaan IMD dipengaruhi oleh berbagai faktor yang dapat dikelompokkan menjadi faktor internal dan eksternal. Faktor internal adalah pengetahuan ibu tentang manfaat IMD, sedangkan faktor eksternal meliputi lingkungan fisik yang mendukung IMD, seperti dukungan dari keluarga dan petugas kesehatan, keterampilan tenaga kesehatan, sarana kesehatan, dan kebijakan pemerintah (Sika-Bright \& Oduro, 2013; Teka dkk., 2015).

Praktik IMD pada ibu yang memiliki anak usia 0-24 bulan di Kota Medan masih belum optimal. Rendahnya cakupan IMD terlihat dari data yang menunjukkan bahwa persentase responden yang melakukan praktik IMD hanya sekitar 64,5\% (Gambar 2). Angka ini sedikit lebih lebih tinggi dari praktik IMD di tingkat provinsi dan nasional yang nilainya masing-masing adalah $39,4 \%$ dan 58,2\% (Balitbangkes Kemenkes, 2019a).

Hasil analisis data survei tentang praktik IMD di Kota Medan cukup bervariasi dan berkaitan dengan beberapa faktor seperti metode persalinan, tempat persalinan serta tingkat pendidikan ibu. Untuk metode persalinan, praktik IMD dengan durasi kurang lebih selama satu jam pada ibu yang melakukan persalinan secara normal $(26,4 \%)$ memiliki probabilitas dua kali lebih baik daripada ibu yang melakukan persalinan melalui operasi sesar $(13,8 \%)$. Hasil wawancara menggambarkan bahwa kondisi fisik ibu yang masih lemah dan di bawah pengaruh anestesi (obat bius) pada saat operasi menjadi hambatan melaksanakan IMD.

Karena saya operasi, makanya IMD itu dikasih pas sudah sore. Karena menunggu kondisi saya pulih dulu juga. Sebenernya kalau kondisi fisik si ibu memungkinkan nggak apa-apa langsung disusui atau IMD untuk bayinya. Tapi karena kondisi saya ga memungkinkan makanya baru sorenya bisa IMD. Saya waktu habis operasi soalnya harus transfusi darah makanya tidak memungkinkan (YS, SMA ke atas, bekerja)

Padahal itu sebelum melahirkan ya, kami sudah tandatangan, suami yang teken yang bunyinya kalau bayi lahir minta untuk IMD... Tapi itu hanya di atas kertas. Karena saya masih lemas sehabis operasi, tidak langsung IMD... Dan di rumah sakit itu ruang ibu dan bayi tidak satu lantai. Jadi, seperti yang habis melahirkan operasi seperti saya agak susah, saya harus minta suster untuk dibawa bayinya, itupun dikasihnya hanya sebentar (M, SMA ke atas, bekerja)

Faktor lain yang menghambat praktik IMD juga disebabkan kurangnya dukungan dari petugas kesehatan dan sarana kesehatan yang kurang 
memadai untuk praktik IMD. Hasil analisis juga mengindikasikan bahwa praktik IMD dipengaruhi oleh kebijakan rumah sakit yang tidak menempatkan bayi dalam satu ruangan dengan ibu. Persentase praktik IMD lebih tinggi sekitar dua kali lipat pada kelompok ibu yang bayinya ditempatkan pada ruangan yang sama dengan ibu $(48,7 \%)$ dibandingkan dengan kelompok ibu yang bayinya diletakkan secara terpisah $(24,8 \%)$.

Kalau saya dari awal itu sudah berusaha mencari rumah sakit yang menerapkan IMD tapi kenyataan yang saya hadapi berbeda. Setelah melahirkan dan saya minta anak saya untuk IMD, orang rumah sakitnya bilang kalau nanti anaknya kedinginan. Akhirnya sama dokter dikasih tapi itu pun tidak lebih dari 10 menit, ya... itu mereka bilang anaknya kedinginan, susu belum keluar. Padahal di otak saya sudah bilang harus 1 jam untuk IMD, tapi ternyata prakteknya tidak bisa. Akhirnya anak saya kena susu formula (NR, SMA ke atas, bekerja)

Dengan demikian, untuk meningkatkan praktik IMD diperlukan promosi kesehatan yang lebih komprehensif dengan mempertimbangkan faktor sosial budaya untuk menghilangkan anggapan yang kurang tepat mengenai kolostrum. Sasaran dari promosi kesehatan tersebut tidak hanya ibu dengan baduta, tetapi juga dengan melibatkan nenek (orang tua ibu). Hal ini dikarenakan pemahaman kolostrum sebagai 'susu basi' seringkali muncul dari mereka. Selain itu, perlu dilakukan monitoring dan evaluasi untuk implementasi kebijakan ibu dan bayi baru lahir dalam ruangan yang sama (room-in policy) pada tiap fasilitas kesehatan sehingga praktik IMD dapat mencegah munculnya kasus status gizi buruk pada baduta di kemudian hari.

\section{Pemberian ASI Eksklusif}

ASI mengandung nutrisi penting yang dibutuhkan oleh bayi dalam enam bulan pertama kehidupan. Cakupan pemberian ASI eksklusif di Kota Medan masih rendah (34,2\%). Angka ini relatif lebih rendah apabila dibandingkan dengan pemberian ASI eksklusif di tingkat nasional pada tahun 2018 yang mencapai 37,3\% (Dinas Kesehatan Provinsi Sumatera Utara, 2019). Dari total 400 ibu, 4,8\% responden sama sekali tidak pernah memberikan ASI kepada bayinya, 61\% ibu memberikan ASI dalam jangka waktu kurang dari enam bulan, dan hanya sekitar $34,2 \%$ ibu yang memberikan ASI eksklusif. Apabila dilihat dari tingkat pendidikan ibu yang memberikan ASI eksklusif, tidak ada perbedaan signifikan antar jenjang pendidikan yang mereka miliki (Gambar 4).

Hasil DKT dengan ibu-ibu yang tinggal di wilayah perkotaan Kota Medan menunjukkan bahwa salah satu faktor kegagalan pemberian ASI eksklusif adalah perasaan khawatir dari ibu akan produksi ASI yang tidak mencukupi kebutuhan nutrisi untuk bayi (Astuti \& Widayatun, 2019). Para ibu umumnya memiliki asumsi seperti ini jika bayi menangis terus-menerus akibat masih lapar meskipun sudah disusui ataupun karena alasan berat badan bayi yang tidak bertambah sesuai dengan usia bayi.

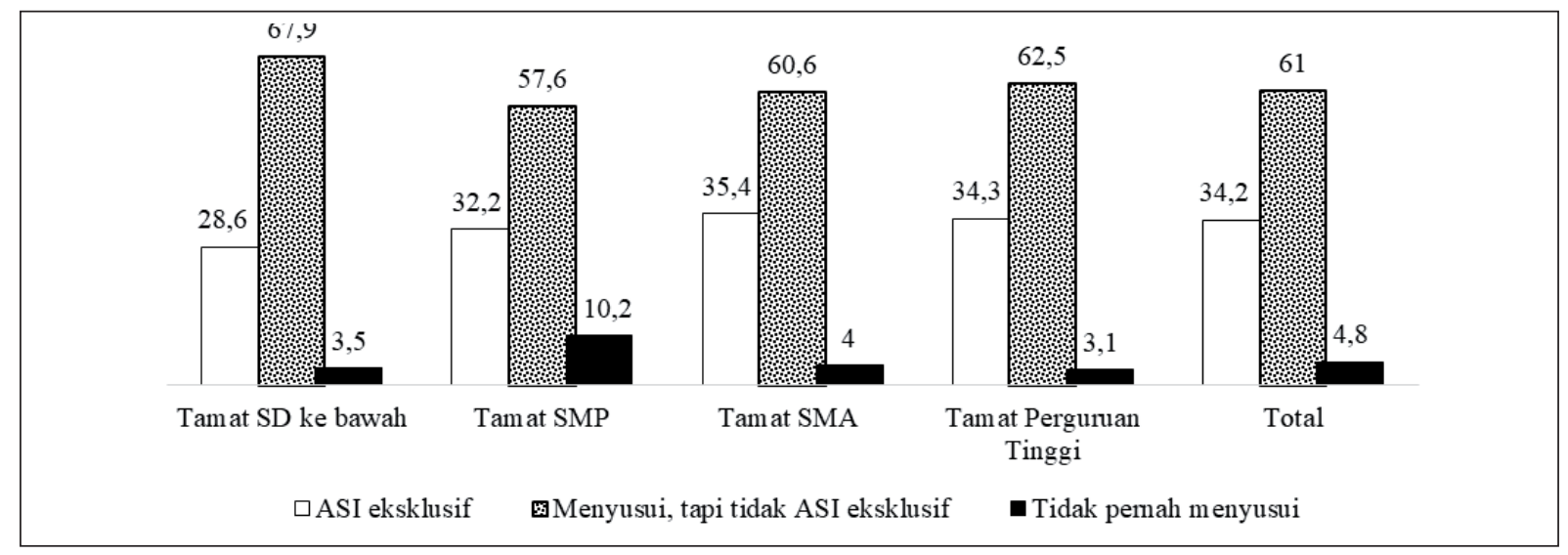

Sumber: Survei determinan sosial perilaku kesehatan ibu dan pola pengasuhan anak di era globalisasi di Kota Medan, P2 Kependudukan LIPI, tahun 2017

Gambar 4. Persentase Pemberian ASI Eksklusif Menurut Tingkat Pendidikan Ibu, Kota Medan, 2017 
Baru 3 hari setelah pulang dari RS bayi mendapatkan ASI. Tapi bayi nangis terus karena ASI belum banyak, akhirnya saya kasih susu formula. Sebenarnya dokter sudah bilang kalau susu formula tidak sebaik ASI. Tapi bagaimana lagi anak saya ini masih menangis terus, pasti saya pikir karena masih lapar kan. Ya sudah saya kasih susu formula saya (US, SMA ke atas, bekerja).

Sebenarnya saya yakin dengan manfaat ASI eksklusif untuk anak, seperti anak jadi jarang sakit. Tapi melihat anak saya nggak naik timbangan, saya jadi kuatir juga. Makanya saya terus berpikir harus dikasih tambahan susu formula (YS, tamat perguruan tinggi, bekerja)

Anak saya itu nangis terus, gak pagi ga siang, habis nyusu juga masih menangis terus. Kata mamak itu perutnya masih lapar. Akhirnya ya sudah saya kasih saja susu formula, mungkin ga cukup ASI saya itu kan (SN, tamat SMA, bekerja)

Pemberian paket susu formula dari petugas kesehatan untuk ibu yang baru melahirkan juga menjadi alasan ibu untuk tidak memberikan ASI eksklusif (Astuti dkk., 2016; Astuti \& Widayatun, 2018a). Hasil uji regresi logistik menunjukkan ibu yang menerima paket susu formula dari petugas kesehatan berpotensi 2,57 kali tidak memberikan ASI eksklusif dibandingkan dengan ibu yang tidak memperoleh paket yang sama. Meskipun Peraturan Pemerintah (PP) No. 33 Tahun 2012 telah melarang semua praktik yang dapat menghambat program pemberian ASI eksklusif, tetapi pemberian bingkisan susu formula untuk ibu yang baru bersalin masih ditemukan di Kota Medan. Lemahnya penerapan PP tersebut ditengarai karena tidak adanya sanksi yang jelas apabila petugas kesehatan melanggar aturan tersebut.

Ibu dengan tingkat sosial ekonomi menengah ke bawah dan pengetahuan yang terbatas umumnya mengungkapkan bahwa praktik pemberian bingkisan berupa susu formula memengaruhi pemberian ASI eksklusif. Temuan ini sejalan dengan penelitian yang dilakukan di Ghana yang menyebutkan keberhasilan ibu yang tinggal di daerah perdesaan untuk memberikan ASI eksklusif lebih rendah dibandingkan dengan ibu yang tinggal di perkotaan. Hal ini dipengaruhi oleh tingkat pendidikan dan kondisi sosial ekonomi di perdesaan yang lebih rendah. Selain itu, keterbatasan akses terhadap penyuluhan kesehatan di daerah perdesaan menjadi salah satu kendala program pemberian ASI eksklusif (Sika-Bright \& Oduro, 2013).

Kalau saya itu habis melahirkan di ibu bidan
dapat hadiah susu kotak seperti yang di TV.
Kalau liat di TV itu kan anak yang dapat susu
kotak badannya gemuk-gemuk, sehat-sehat. Jadi
ya saya kasih saja susu yang dari ibu bidan. Pas
hadiahnya habis itu saya beli juga susu kotaknya
yang sama. Harganya tidak murah, saya pikir
itu pasti lebih bagus dari ASI (AN, tamat SD,
tidak bekerja)

Kalau melahirkan di bidan itu kan memang dikasihnya susu kotak pakai dot-dot, sayang itu kalau mau dibuang atau di kasih orang harganya kan mahal, jadi itu sudah pasti bagus. Yang kasih kan ibu bidan juga, artinya itu bagus untuk bayi (Hasil DKT dengan ibu rumah tangga)

Sebenarnya kalau kita melahirkan kan itu dapat bingkisan dari ibu bidan. Padahal kita itu yang sebenarnya sudah bayar untuk bingkisan susu formula. Masa kita mau buang-buang uang yang sudah kita keluarkan. Tidak murah sekarang melahirkan di bidan, bisa 1,5 juta. Jadi itu sebenarnya termasuk biaya susu. Sayang-sayang kalau tidak kasih susu ke bayi, kan sudah bayar mahal (Hasil DKT dengan ibu rumah tangga)

Hasil analisis data kuantitatif menunjukkan kegagalan pemberian ASI eksklusif di Kota Medan juga disebabkan karena ibu bekerja. Seki$\operatorname{tar} 63,2 \%$ ibu bekerja di Kota Medan tidak memberikan ASI eksklusif dengan berbagai alasan, misalnya menyusui selama bekerja dianggap merepotkan. Hal ini disebabkan karena tidak ada tempat khusus yang dapat dimanfaatkan sebagai ruang laktasi maupun sarana penyimpanan ASI yang memadai. Pemerintah melalui Peraturan Menteri Kesehatan (Permenkes) No. 15 Tahun 2013 sudah mengatur tata cara penyediaan fasilitas khusus menyusui dan atau memerah ASI untuk tempat kerja. Namun, implementasi Permenkes tersebut masih menghadapi berbagai kendala untuk diterapkan di lapangan, khususnya di Kota Medan. Hasil kutipan wawancara mendalam dengan ibu dan nenek menggambarkan berbagai alasan kegagalan ASI eksklusif pada ibu bekerja. 
Jadi anak saya itu dapat susu formula selain ASI setelah lahir, karena kan saya bekerja. Tapi kalau saya di rumah saya kasih ASI, kasih susu kalau pas ditinggal kerja saja. Ibu saya yang suruh anak kasih susu formula supaya saya tenang bekerjanya... Saya malas juga pompa ASI kaya orang-orang sekarang karena repot kasihnya, mau disimpan dimana juga susu yang diperah itu (Hasil DKT dengan ibu-ibu bekerja)

Saya itu prinsipnya dan bilang ke anak saya, kalau dia ada di rumah jangan kasih anak susu formula tapi disusui langsung saja. Tapi karena sambil kerja, ya sudahlah kasih aja susu formula. Kalau dulu anak saya ini (SN) saya kasih ASI terus, tapi kan saya di rumah nggak kerja jadi ya bisa lah dapat ASI sampai puas dia ini... Toh bekerja kan cari uang untuk anak, jadi ya tidak apa-apa di kasih susu formula saja. Sama saja semua bagus, ASI bagus, susu formula juga bagus (Nenek atau orang tua $\mathrm{SN}$ )

Kita kerja itu kan buat anak. Susu formula semua tau harganya mahal, jadi pasti itu bagus untuk anak, bergizi tinggi. Tak apa kita kerja capek, tapi hasilnya buat susu anak, semua demi kesehatan anak. Liat juga kan kalau minum susu formula itu anak badannya jadi bagus, lebih cepat gemuk dibandingkan anak yang cuma ASI (Hasil DKT dengan ibu-ibu bekerja)

Saya itu kan bekerja, maunya tetap kasih ASI eksklusif. Tapi bagaimana kalau habis memompa itu mau disimpan dimana ASI saya. Di kantor tidak ada kulkas untuk menyimpan. Belum lagi kadang kita itu harus memompa ASI di kamar mandi, karena kan kalau di ruangan kerja itu banyak orang. Banyak bapak-bapak juga jadi kurang nyaman. Jadi supaya praktis, ya sudah saya kasih saja susu formula ke bayi ketika saya harus kembali bekerja (NV, tamat perguruan tinggi, bekerja)

Sejalan dengan temuan penelitian sebelumnya yang menyebutkan menyusui menjadi sebuah permasalahan kompleks bagi ibu bekerja dengan alasan waktu atau sarana yang tidak mendukung (Liamputtong, 2011). Hasil penelitian yang sama menunjukkan ibu bekerja memberikan ASI lebih singkat dibandingkan dengan ibu yang tidak bekerja.

Selain itu, berdasarkan informasi yang diperoleh dari ibu bekerja dengan tingkat pendidikan rendah, mereka umumnya memiliki pemahaman yang kurang tepat terkait dengan manfaat ASI eksklusif. Sebagian ibu masih memiliki anggapan bahwa susu formula memiliki nutrisi yang setara dengan ASI eksklusif. Harga susu formula yang cukup mahal menjadi justifikasi bagi ibu bahwa susu formula memiliki manfaat yang lebih baik dibandingkan dengan memberikan ASI eksklusif kepada bayi mereka (Astuti \& Widayatun, 2018a; Astuti dkk., 2016).

Hasil survei mengindikasikan bahwa dukungan suami dan anggota keluarga lainnya turut berperan dalam menentukan keberhasilan pemberian ASI eksklusif. Bentuk dukungan yang diberikan dapat berupa suami menyediakan makanan bergizi yang dapat meningkatkan produksi ASI, suami bersedia untuk berbagi pekerjaan rumah tangga dengan istri ataupun suami bersedia untuk menemani istri pada saat menyusui, khususnya di malam hari (Astuti \& Widayatun, 2019).

Motivasi ibu menjadi salah satu faktor penting yang menentukan keberhasilan pemberian ASI eksklusif. Seperti yang diungkapkan oleh Thulier dan Mercer (2009) yang menyebutkan bahwa motivasi ibu maternal untuk menyusui adalah kunci kesuksesan pemberian ASI. Hal ini sesuai dengan temuan di lapangan yang terlihat dalam kutipan wawancara berikut.

Saya itu tidak hanya dengar dari mama pentingnya ASI tapi juga suka baca di internet kenapa bayi sampai 6 bulan cukup dikasih ASI. Alasan lainnya saya ingin kasih ke anak saya paling tidak sama seperti yang saya dapatkan dari mama. Artinya begini, kalau saya dulu dikasih ASI eksklusif maka anak saya juga harus dapat... Bekerja, saya bisa pulang pas istirahat untuk menyusui anak saya. Atau saya biasanya pompa juga kalau pagi sebelum berangkat dan pas di kantor. Tapi memang dukungan dari mama salah satu alasan berhasil kasih ASI eksklusif untuk kedua anak saya. Selain itu, saya ikut grup yang ada di Facebook kelompok ibuibu yang ASI eksklusif walaupun bekerja. Nah hal-hal seperti itu yang memotivasi saya untuk tetap kasih ASI eksklusif ke anak, kasih yang terbaik (PT, SMA ke atas, bekerja)

\section{Praktik Pemberian Makanan Pendamping ASI}

Kebutuhan gizi akan meningkat setelah bayi berusia enam bulan dan tidak dapat terpenuhi hanya dari pemberian ASI. Pada periode 6-24 bulan 
diperlukan makanan pendamping ASI untuk melengkapi kebutuhan tumbuh kembang anak. Hasil survei menunjukkan $41,5 \%$ ibu dengan tingkat pendidikan tamat SMP ke bawah memberikan makanan pendamping ASI ketika bayi berusia kurang dari enam bulan. Jenis makanan pendamping ASI ketika anak berusia kurang dari enam bulan meliputi pisang, bubur beras maupun makanan cepat saji untuk balita. Hasil survei di Kota Medan juga menunjukkan 40,6\% ibu dengan tingkat pendidikan tinggi (tamat SMA dan perguruan tinggi) memberikan makanan pendamping ASI berupa susu formula. Seperti dijelaskan sebelumnya, hal ini sejalan dengan rendahnya pemberian ASI eksklusif di Kota Medan.

Berdasarkan hasil wawancara diketahui pemberian makanan pendamping ASI sering kali dipengaruhi oleh keputusan nenek (orang tua ibu) dengan berbagai alasan pengalaman yang dimilikinya. Temuan seperti ini umumnya terjadi pada baduta yang diasuh oleh neneknya selama ibu bekerja. Kutipan wawancara dan hasil DKT menjelaskan berbagai alasan pemberian makanan pendamping ASI sebelum bayi berusia enam bulan.

Bayi yang baru lahir usia satu bulan sudah dikasih pisang yang dikerok. Harusnya ga boleh kan bu...tapi anaknya ga bisa diam. Kalau ga pisang ya dikasih SUN bubur bayi (Hasil DKT dengan ibu rumah tangga)

Kalau aku 3 bulan bayinya aku kasih makan... nggak apa-apa itu bu, sehat terus kok sampai sekarang. Aku kasih bubur, bubur beras merah, Promina yang encer. Habis anak menangis terus, kata orang ini masih lapar (Hasil DKT dengan ibu bekerja)

Kalau dulu ibunya bayi ini kan juga saya kasih bubur sama pisang kerok pas umur 3 bulan. Jadi sama saja untuk cucu saya. Itu buktinya anak saya sampai sekarang sehat-sehat saja. Jadi biar kenyangnya itu mantap kalau dapat makan, tidurnya bisa nyenyak... Anak saya juga tidak pernah tanya ini bayinya dikasih apa, karena kan dia tau saya ini sudah pengalaman banyak anak. Anak saya 4 semuanya saya kasih makan cepat, semua baik-baik saja (nenek, orang tua SN)

Kan sudah terlanjur kena susu formula juga, jadi kalau ibunya kerja kan saya yang urus ini cucu saya. Saya kasih pisang kerok, bukan bubur instan tapi buah supaya tambah sehat cucu saya ini... ibunya ini tau kalau anaknya saya suka kasih buah. Dia ikut saja apa yang saya kasih, karena dia tau juga kan ini menyehatkan buat anaknya (nenek, orang tua LN)

Terkait dengan tradisi atau praktik budaya di kalangan penduduk Kota Medan, hasil survei menunjukkan $67,5 \%$ ibu masih melakukan tradisi bagi bayi baru lahir. Sebagai contoh, mengoleskan madu $(43,7 \%)$ dan mengoleskan gula (48,5\%) pada bibir bayi. Menurut pengakuan ibu, kepercayaan ini memiliki makna gula atau madu yang memiliki rasa manis dipercaya akan memberikan kehidupan yang baik di masa depan untuk bayi baru lahir (Astuti \& Widayatun, 2018b). Praktik pemberian makanan prelakteal seperti ini tanpa disadari akan menghambat pemberian ASI eksklusif. Studi terkait menyebutkan pemberian makanan pendamping ASI sebelum anak berusia enam bulan berpotensi untuk menyebabkan stunting 1,21-2,98 lebih tinggi dibandingkan anak yang memperoleh makanan pendamping ASI pada usia yang tepat (Berhe dkk., 2019; Bukusuba dkk., 2018; Kim dkk., 2017). Oleh karena itu, untuk mencegah pemberian makanan prelakteal dan makanan pendamping ASI yang kurang tepat, perlu dilakukan inovasi untuk promosi kesehatan (seperti kegiatan posyandu) dengan melibatkan ibu dengan baduta dan nenek (orang tua ibu).

\section{KESIMPULAN}

Hingga saat ini, Kota Medan masih menghadapi berbagai permasalahan status gizi baduta. Kondisi ini tidak terlepas dari pengasuhan anak pada 1.000 HPK yang belum optimal. Dalam studi ini, pola pengasuhan anak dilihat dari indikator pemberian kolostrum, praktik IMD, pemberian ASI eksklusif, dan pemberian makanan pendamping ASI. Hasil olah data kuantitatif dan kualitatif menunjukkan faktor sosial ekonomi seperti tingkat pendidikan ibu, status ibu bekerja dan metode persalinan terbukti memengaruhi pola pengasuhan anak pada periode $1.000 \mathrm{HPK}$. Selain itu, faktor budaya dan peran petugas kesehatan memainkan peran dalam menentukan status gizi baduta di Kota Medan. 
Pemberian kolostrum untuk bayi baru lahir di Kota Medan masih sangat kental dipengaruhi oleh faktor budaya yang menganggap kolostrum sebagai 'susu basi' sehingga harus dibuang dan tidak layak diberikan untuk bayi baru lahir. Untuk praktik IMD, peran petugas kesehatan dan kebijakan rumah sakit, khususnya penempatan bayi yang baru lahir dalam ruangan sama dengan ibu, menentukan keberhasilan IMD. Pemberian ASI eksklusif menunjukkan tidak adanya perbedaan tingkat pendidikan ibu. Ibu dengan tingkat pendidikan rendah seperti sudah diperkirakan, memiliki pemahaman terbatas mengenai manfaat ASI eksklusif. Sementara itu, ibu bekerja menyebutkan ketersediaan fasilitas laktasi di tempat kerja mereka sebagai penghalang keberhasilan praktik ASI eksklusif. Menariknya, pemberian bingkisan berupa paket susu formula bagi ibu yang baru melahirkan juga masih ditemukan di Kota Medan. Untuk pemberian makanan pendamping ASI yang kurang tepat, umumnya dipengaruhi oleh pengalaman nenek (orang tua ibu). Praktik tradisi untuk bayi baru lahir di Kota Medan, seperti mengoleskan madu atau gula, juga ditengarai melemahkan praktik pemberian ASI eksklusif.

Hasil studi ini merekomendasikan diperlukannya inovasi dalam promosi kesehatan, khususnya untuk pengasuhan $1.000 \mathrm{HPK}$, yang lebih inovatif dengan memperhatikan faktor sosial budaya di Kota Medan. Promosi kesehatan tidak hanya ditujukan untuk ibu dengan baduta sebagai kelompok sasaran tetapi juga dengan melibatkan nenek (orang tua ibu). Selain itu, diperlukan monitoring dan evaluasi terkait implementasi kebijakan untuk fasilitas laktasi di ruang publik dan perkantoran di Kota Medan. Perlu adanya teguran dan sanksi terhadap rumah sakit, rumah bersalin, dan fasilitas kesehatan lainnya yang tidak menempatkan ibu dan bayi baru lahir dalam satu ruangan yang sama. Aturan dan sanksi yang jelas juga perlu diterapkan bagi pengelola fasilitas kesehatan yang masih memberikan susu formula sebagai bingkisan kepada ibu bersalin.

\section{DAFTAR PUSTAKA}

Aguayo, V. M., \& Menon, P. (2016). Stop stunting: Improving child feeding, women's nutrition and household sanitation in South Asia. Maternal \& Child Nutrition, 12, 3-11. https:// doi.org/10.1111/men. 12283

Alderman, H., Hentschel, J., \& Sabates, R. (2003). With the help of one's neighbours: Externalities in the production of nutrition in Peru. Food and Nutrition Bulletin, 4(4), 2019-2031. https://doi.org/10.1016/s02779536(02)00183-1

Astuti, Y., \& Widayatun. (2018a). Determinan perilaku kesehatan ibu pada masa kehamilan: Kasus Kota Medan. Jurnal Kependudukan Indonesia, 13(1), 39-54. https://doi. org/10.14203/jki.v13i1.322

Astuti, Y., \& Widayatun. (2018b, Juli). Faktor sosial budaya dalam pengasuhan anak di Kota Medan, Sumatera Utara [Presentasi makalah]. Widyakarya Nasional Pangan dan Gizi XI, Jakarta.

Astuti, Y., \& Widayatun. (2019). Peningkatan kesehatan ibu dan anak: Tantangan sosial budaya. Yayasan Pustaka Obor.

Astuti, Y., Widayatun, \& Rahadian, A.S. (2016). Pola pengasuhan bayi pada periode emas kehidupan: Peran dan interaksi keluarga di era globalisasi. Pusat Penelitian Kependudukan LIPI.

Aubel, J. (2011). The role and influence of grandmothers on child nutrition: Culturally designated advisors and caregivers. Maternal and Child Nutrition, 2012(8), 19-35. https:// doi.org/10.1111/j.1740-8709.2011.00333.x

Badan Penelitian dan Pengembangan Kesehatan Kementerian Kesehatan (Balitbangkes Kemenkes). (2019a). Laporan riset kesehatan dasar 2018. Balitbangkes Kemenkes.

Badan Penelitian dan Pengembangan Kesehatan Kementerian Kesehatan (Balitbangkes Kemenkes). (2019b). Indeks pembangunan kesehatan masyarakat tahun 2018. Balitbangkes Kemenkes.

Batiro, B., Demissie, T., Halala, Y., \& Anjulo, A. A. (2017). Determinants of stunting among children aged 6-59 months at Kindo Didaye Woreda, Wolaita Zone, Southern Ethiopia: Unmatched case control study. PLoS One, 12(12), e0189106. https://doi.org/10.1371/ journal.pone. 0189106 
Bbaale, E. (2014). Maternal education and child nutritional status: Evidence from Uganda. African Journal of Economic and Management Studies, 5(1), 52-74. https://doi.org/10.1108/ AJEMS-06-2012-0040

Berhe, K., Seid, O., Gebremariam, Y., Berhe, A., \& Etsay, N. (2019). Risk factors of stunting (chronic undernutrition) of children aged 6 to 24 months in Mekelle City, Tigray Region, North Ethiopia: An unmatched case-control study. PLoS One, 14(6), e0217736. https://doi. org/10.1371/journal.pone.0217736

Black, R. E., Allen, L. H., Bhutta, Z. A., Caulfield, L. E., De Onis, M., Ezzati, M., Mathers, C., \& Rivera, J. (2008). Maternal and child undernutrition: Global and regional exposures and health consequences. The Lancet, 371(9608), 243-260. https://doi.org/10.1016/ S0140-6736(07)61690-0

Black, R. E., Victora, C. G., Walker, S. P., Bhutta, Z. A., Christian, P., De Onis, M., Ezzati, M., Grantham-McGregor, S., Katz, J., Martorell, R., \& Uauy, R. (2013). Maternal and child undernutrition and overweight in low-income and middle-income countries. Lancet, 382, 427-451. https://doi.org/10.1016/S01406736(13)60937-X

Bukusuba, J., Kaaya, A. N., \& Atukwase, A. (2018). Modelling the impact of stunting on child survival in a rural Ugandan setting. $B M C$ Nutrition, 4, 13. https://doi.org/10.1186/ s40795-018-0220-4

Dinas Kesehatan Provinsi Sumatera Utara. (2019). Profil kesehatan Provinsi Sumatera Utara tahun 2018. Dinas Kesehatan Sumatera Utara. https://www.kemkes.go.id/ resources/download/profil/PROFIL_KES PROVINSI_2018/02_Sumut_2018.pdf

Fouts, H. N., Roopnarine, J. L., Lamb, M.E., \& Evans, M. (2012). Infant social interactions with multiple caregivers: The importance of ethnicity and socioeconomic status. Journal of Cross-Cultural Psychology, 43(2), 328-348. https://doi.org/10.1177/0022022110388564

Frosta, M. B., Forsteb, R., \& Haas, D. W. (2005). Maternal education and child nutritional status in Bolivia: Finding the links. Social Science \& Medicine, 60(2005), 395-407. https://doi. org/10.1016/j.socscimed.2004.05.010

Gross, F. D. M., Sand, I. C. P. V. D., Girardon-Perlini, N. M. O., \& Cabral, F. B. (2011). Influence of grandmothers on infant feeding: What they say to their daughters and granddaughters. Acta Paul Enferm, 24(4), 534-540. https:// doi.org/10.1590/S0103-21002011000400014
Ingram, J., Johnson, D., \& Hamid, N. (2003). South Asian grandmothers' influence on breast feeding in Bristol. Midwifery, 19, 318-327. https://doi.org/10.1016/S0266-6138(03)000457

Kahssay, M., Woldu, E., Gebre, A., \& Reddy, S. (2020). Determinants of stunting among children aged 6 to 59 months in pastoral community, Afar Region, North East Ethiopia: Unmatched case control study. BMC Nutrition, 6, 9. https://doi. org/10.1186/s40795-020-00332-z

Kementerian Kesehatan. (2018). Menyusui sebagai dasar kehidupan. Pusat Data dan Informasi, Kementerian Kesehatan. https://www.kemkes. go.id/article/view/19011500003/menyusuisebagai-dasar-kehidupan.html

Kementerian Kesehatan. (2020). Profil kesehatan Indonesia tahun 2019. Kementerian Kesehatan. https://pusdatin.kemkes.go.id/resources/ download/pusdatin/profil-kesehatan-indonesia/ Profil-Kesehatan-indonesia-2019.pdf

Katepa-Bwalya, M., Mukonka, V., Kankasa, C., Masaninga, F., Babaniyi, O., \& Siziya, S. (2015). Infant and young children feeding practices and nutritional status in two districts of Zambia. International Breastfeeding Journal, 19(5). https://doi.org/10.1186/ s13006-015-0033-x

Kim, R., Mejia-Guevara, I., Corsi, D. J., Aguayo, V. M., \& Subramanian, S. V. (2017). Relative importance of 13 correlates of child stunting in South Asia: Insights from nationally representative data from Afghanistan, Bangladesh, India, Nepal, and Pakistan. Social Science and Medicine, 187, 144-154. https:// doi.org/10.1016/j.socscimed.2017.06.017

Liamputtong, P. (2011). Infant feeding practices: $A$ cross-cultural perspective. Springer.

Masvie, H. (2006). The role of Tamang mothers-inlaw in promoting breast feeding in Makwanpur District, Nepal. Midwifery, 22, 22-31. https:// doi.org/10.1016/j.midw.2005.02.003

Meedya, S., Fahy, K., \& Kable, A. (2010). Factors that positively influence breastfeeding duration to 6 months: A literature review. Women and Birth, 23, 135-145. https://doi.org/10.1016/j. wombi.2010.02.002

Mekuria, G., \& Edris, M. (2015). Exclusive breastfeeding and associated factors among mothers in Debre Markos, Northwest Ethiopia: A cross-sectional study. International Breastfeeding Journal, 10(1). https://doi. org/10.1186/s13006-014-0027-0

Mullany, L. C., Katz, J., Li, Y. M., Khatry, S. K., LeClerg, S. C., Darmstadt, G. L., \& Tielsch, 
J. M. (2008). Breastfeeding patterns, time to initiation and mortality risk among newborns in Southern Nepal. Journal of Nutrition, 138, 599-603. https://doi.org/10.1093/jn/138.3.599

Onah, S., Osuorah, D. I. C., Ebenebe, J., Ezechukwu, C., Ekwochi, U., \& Ndukwu, I. (2014). Infant feeding practices and maternal sociodemographic factors that influence practice of exclusive breastfeeding among mothers in Nnewi South-East Nigeria: A crosssectional and analytical study. International Breastfeeding Journal, 9(6). https://doi. org/10.1186/1746-4358-9-6

Perkins, J. M., Kim, R., Krishna, A., McGovern, M., Aguayo, V. M., \& Subramanian, S. V. (2017). Understanding the association between stunting and child development in low-and middleincome countries: Next steps for research and intervention. Social Science and Medicine, 193, 101-109. https://doi.org/10.1016/j. socscimed.2017.09.039

Saaka, M. (2014). Relationship between mothers' nutritional knowledge in childcare practices and the growth of children living in impoverished rural communities. Journal of Health, Population, and Nutrition, 32(2), 237-248.

Sika-Bright, S., \& Oduro, G. Y. (2013). Exclusive breastfeeding practices of mothers in Duakor, a traditional migrant community in Cape Coast, Ghana. Journal of Global Initiatives: Policy, Pedagogy, Perspective, 8(1).

Tariku, A., Biks, G. A., Derso, T., Wassie, M. M., \& Abebe, S. M. (2017). Stunting and its determinant factors among children aged 6-59 months in Ethiopia. Italian Journal of Pediatrics, 43(1), 112. https://doi.org/10.1186/ s13052-017-0433-1

Teka, B., Assefa, H., \& Haileslassie, K. (2015). Prevalence and determinant factors of exclusive breastfeeding practices among mothers in Enderta Woreda, Tigray, North Ethiopia: A cross-sectional study. International Breastfeeding Journal, 10(2). https://doi.org/10.1186/s13006-014-0028-z

Thulier, D., \& Mercer, J. (2009). Variables associated with breastfeeding duration. Journal of Obstetric, Gynecologic, \& Neonatal Nursing, 38, 259-268. https://doi.org/10.1111/j.15526909.2009.01021.x

UNICEF [United Nations Children's Fund]. (2013). Improving child nutrition: The achievable imperative for global progress. UNICEF. https://www.unicef.org/publications/files/ Nutrition_Report_final_lo_res_8_April.pdf

Victora, C. G., Adair, L., Fall, C., Hallal, P. C., Martorell, R., Richter, L., \& Sachdev, H. S. (2008). Maternal and child undernutrition: Consequences for adult health and human capital. The Lancet, 371(9609), 340-357. https://doi.org/10.1016/s0140-6736(07)616924

Wagner, C. L., Wagner, M. T., Ebeling, M., Chatman, K. G., Cohen, M., \& Hulsey, T. C. (2006). The role of personality and other factors in a mother's decision to initiate breastfeeding. Journal of Human Lactation, 22(1). https:// doi.org/10.1177/0890334405283624

WHO [World Health Organization]. (2013). Childhood stunting: Challenges and opportunities. https://apps.who.int/iris/bitstream/ handle/10665/107026/WHO NMH NHD GRS 14.1 eng.pdf;jsessionid=AF6B06E1F4 0054399A91A61B774A0E03? sequence $=1$

Young, M. F., Nguyen, P. H., Gonzalez Casanova, I., Addo, O. Y., Tran, L. M., Nguyen, S., Martorell, R., \& Ramakrishnan, U. (2018). Role of maternal preconception nutrition on offspring growth and risk of stunting across the first 1000 days in Vietnam: A prospective cohort study. PLoS One, 13(8), e0203201. https://doi.org/10.1371/journal.pone.0203201 